\title{
Review
}

\section{Integrated Watershed Management Framework and Ground- water Resources in Africa- A Review of West Africa Sub-region}

\author{
John Adekunle Adesina ${ }^{1, *}$, Jiang Jiang ${ }^{2}$ and Tang Xiaolan ${ }^{1,3}$ \\ 1 College of Landscape Architecture, Nanjing Forestry University, Nanjing, 210037, China; adesina- \\ johnlloyd@gmail.com \\ 2 College of Ecology, Nanjing Forestry University, Nanjing, 210037, China; ecologyjiang@gmail.com \\ 3 NFU Academy of Chinese Ecological Progress and Forestry Studies, Nanjing, 210037, China; \\ xiaolant@njfu.edu.cn. \\ * Correspondence: adesinajohnlloyd@gmail.com; ecologyjiang@gmail.com; xiaolant@njfu.edu.cn.
}

\begin{abstract}
Human activities mostly impact the trend and direction of surface water, groundwater, and other river basin resources in the watershed in Africa. Human activities influence river flows and the water quality at both highlands and lowlands. A watershed is indeed a conserved area of land that collects rain and snow and empties or penetrates into ground water sources. The act of managing the activities around the watershed is the Integrated Watershed Management while considering the social, economic, and environmental issues, as well as community interests to manage water resources sustainably. These watersheds, river basins, and groundwater resources provide important services for communities and biodiversity. This paper reveals that the best way to protect groundwater resources is on a watershed basis using IWM. This technique enables us to handle a variety of concerns and objectives while also allowing us to plan in a complicated and uncertain environment. IWM involves cooperation and participation from a wide range of community interests and water users, including municipalities, companies, people, agencies, and landowners, for stakeholders' input to be successful. All of the strategies and plans are produced concerning one another, as well as the overall conditions of the watershed, local land uses, and specific issues.
\end{abstract}

Keywords: Africa; Biodiversity; Groundwater Resources; Integrated Watershed Management; River Basin.

\section{Introduction}

A watershed is a biophysically defined region delimited by water flow and drained by a current or series of currents to a single exit point or gathering area [1]. A "land area that drains into a stream" is referred to as a watershed [2]. "The use, management, and investment in multiple interrelated resources within watersheds" is what watershed management entails. It refers to the management of all natural resources in a watershed, including forests and other land uses, as well as water. Watersheds are distinct locations that are generally defined by a diversity of ecological and socioeconomic characteristics [1].

The interests of stakeholders, who might differ across upstream and downstream consumers as well as between sectors of the economy, are, nevertheless, extremely complicated. "Watersheds are usually large, and several people, companies and groups are willing to participate in how they are managed." [3]. Water, soil, nutrients, and pollutants move across various areas of a watershed, forming physical links between individuals who are geographically apart [3]. Watersheds are brimming with production and consumption externalities in economic terms. It has long been understood that water resources are inextricably linked to the ecosystem and people who live in it. The increased focus on watershed management can also be seen in the large amount of money invested 
in watershed projects in recent years [3]. Even though the focus of this review paper is on the Assessment of Integrated Watershed Management, River Basin Framework, and Groundwater Resources in Africa, other natural resources in the watershed are taken into account to the extent that they are directly related to water issues. The focus of this report is on the evaluation of integrated watershed management, river basin framework, and groundwater resources in Africa, as well as the river basin organizations (RBOs) and institutions that regulate and use them.

\section{Watershed Management in Africa}

A drainage basin is a land area where water flows and drains into a widespread water body, including a stream, lagoon, lake, or coasts [4]. A watershed is a natural system that includes water, plants, animals, marshes, moraines, and forests that interact [5]. The watershed border will roughly follow the highest ridgeline surrounding the stream channels, eventually meeting at the bottom or lowest point of the land, the mouth of the canal, when water flows out of the watershed. Rainfall and storm water runoff provide the majority of the water. All changes to the land, such as mining, agriculture, highways, urban development, and human activities within a watershed, have an impact on the quality and amount of storm water. Naturally raised places are designated to divide watersheds from one another [5].

\subsection{Why is Watershed and Groundwater Resources Important?}

Surface water features and storm water runoff within a watershed eventually flow to other bodies of water, making watersheds significant. When executing water quality protection, sustenance and restoration initiatives, it is critical to consider these downstream effects [5]. Everything that happens upstream eventually ends up downstream. We must keep in mind that we all live downstream and that our daily actions might have an impact on downstream rivers. Environmental management has traditionally been focused on individual concerns such as air, land, and water [6]. The majority of these efforts have resulted in lower pollutant emissions to the air and water, improved landfills, waste sites, and contaminated groundwater remediation, protection of rare and endangered species, development of best management practices to control water and contaminant runoff, and much more. Nonpoint source pollution and habitat loss continue to be a challenge for our seas. These are the issues that are causing the majority of the water quality issues across the board. These are often difficult-to-manage complicated challenges. Nonpoint pollution and habitat degradation are often considered to be cross-program issues [7].

The erosion and watershed management projects primarily aim to minimize soil erosion susceptibility in designated sub-watersheds throughout Africa, and more specifically in East Africa. Erosion and watershed management infrastructure investments component will support on-the-ground interventions to help reduce vulnerability to land degradation; Erosion and watershed management institutions and information services will strengthen the enabling environment for effective erosion and watershed management implementation. These strategies will lead to improved capacities, modernization, and coordination of relevant federal, state, and local institutions involved in investment planning, management, assessment, enforcement, and monitoring of watershed and erosion-related activities, as well as disaster risk management; the climate change response component will include actions that contribute to strengthening Nigeria's strategic framework for climate action [8].

Watershed management's ultimate goal is to maintain a balanced social, economic, and ecological watershed function, therefore contributing to long-term development and the decrease of negative external consequences in an area action [8]. This assumes that at the regional level, proper policies, regulations, and institutions are in place and respected. The goal establishes a framework for achieving the following major watershed man- 
agement objectives: ensuring that beneficial uses of water resources and other related resources are maintained, achieving specified and agreed-upon management targets for water and related resources, avoiding negative off-site impacts (externalities) on water and related resources, and recognizing and avoiding negative human impacts on watershed functions. It also helps to promote social and economic growth, to protect, reduce, or repair natural resources and the environment, reduce local susceptibility to climate extremes, and maintain biodiversity action [9].

The aforementioned watershed management goals are dependent on country-specific circumstances, as well as the priorities of higher-ranking development programs and plans. These vary significantly between nations, however as one country-specific example action [10]. To attain these goals, a variety of activities and methods are possible, including but not limited to drafting and passing relevant policies and legislation, as well as establishing supporting institutions. Reducing riverbank erosion, minimizing sediment transit and buildup, and increasing water quality are all benefits of managing the river flow regime. This helps to maintain good water quality and supply standards that comply with government regulations and community expectations. Floods, droughts, and landslides are all-natural calamities that may be avoided [6].

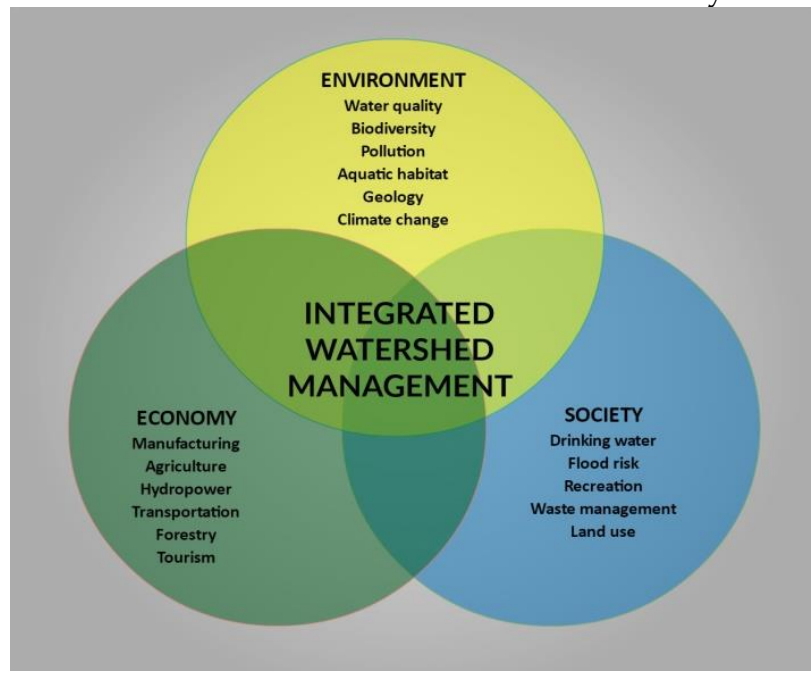

Figure 1: Policy Priorities of Integrated Watershed-Management, https://conservationontario.ca/Conservation Ontario (2012).

Effectively use natural resources to reduce negative consequences, avoid environmental degradation, boost water output, and increase biomass production. Promoting suitable agriculture and forestry land-use practices, as well as accompanying soil and water conservation measures that allow for adequate production levels while minimizing long-term negative consequences on the watershed's natural resources. It promotes economic and human exploration and production through job and income-generating activities. Encourage the use of the development of indigenous technical knowledge and materials through simple, accessible, and economical technology solutions and institutional structures. The economic and social circumstances of the poor and those with limited resources are drastically improved. It also helps in increasing the distribution of the benefits of land and water resources development across stakeholders. Most of these actions and measures have been planned and implemented in the past under the umbrella of watershed management in some form or another. This might explain why there are so many different perspectives and definitions of watershed management [6].

Watershed management has acquired prominence and relevance in both environmental preservation and the well-being of people living in watershed regions during the previous several decades. The Bhutan government, for example, identified watershed management as the "single most critical approach to preserve the resource base to sup- 
port the national economy" in its policy statement [11]. The idea behind watershed management initiatives is that some natural resources are better managed on a watershed scale. Multiple scales and a combination of physical and social variables are prevalent, necessitating an interdisciplinary approach. Due to a variety of physical and social properties, watersheds are considered effective units of analysis and action [12].

Table 1: Showing the physical and social characteristics of Watersheds/Catchment and River basins in Africa.

\begin{tabular}{|c|c|}
\hline $\begin{array}{l}\text { Physical \& Environmental } \\
\text { Factors }\end{array}$ & Characteristics \\
\hline Biophysical System & $\begin{array}{l}\text { Natural biophysical units such as watersheds/catchments and river basins } \\
\text { are useful for monitoring natural processes. }\end{array}$ \\
\hline Multiple Scales & $\begin{array}{l}\text { Watersheds/Catchments and River Basins establish distinct nested land- } \\
\text { scape hierarchies that emphasize biophysical interdependence at several scales. }\end{array}$ \\
\hline Ideal for Process Studies & $\begin{array}{l}\text { Watersheds and river basins allow for mass-balance, input-output, and } \\
\text { water-nutrient analysis, as well as cause-and-effect relationships to be assessed. }\end{array}$ \\
\hline Integrated Framework & $\begin{array}{l}\text { Watersheds take into account all land-use consequences and emphasize the } \\
\text { connections between land use and other natural systems. }\end{array}$ \\
\hline Assist in Addressing Complexity & $\begin{array}{l}\text { Its cumulative impacts can be studied, and interactions between the at- } \\
\text { mosphere, soil, and water can be determined. }\end{array}$ \\
\hline \multicolumn{2}{|l|}{ Socio-cultural Factors } \\
\hline Decision-Making Tool & $\begin{array}{l}\text { As geographic units, watersheds make science-based decisions easier. They } \\
\text { provide a solid foundation for dynamic and adaptable management. }\end{array}$ \\
\hline Transboundary Links & $\begin{array}{l}\text { Watercourses, which include interrelated natural resources, define water- } \\
\text { sheds. Through upstream-downstream flow and continuous coincidence along } \\
\text { river boundaries, this connects countries and regions. }\end{array}$ \\
\hline Social Organization & $\begin{array}{l}\text { Watersheds may constitute a common meeting place for communication, } \\
\text { negotiation, planning, and monitoring as a result of their social construction. }\end{array}$ \\
\hline
\end{tabular}

According to the World Bank report [13], over 64\% of Africa's population lives in rural areas, with many of them on modest subsistence farms. Rockström \& Falkenmark [14] also shared the same opinion about the population of Africa. Rain-fed agriculture accounts for $95 \%$ of cropland in Sub-Saharan Africa, leaving most people highly reliant on the annual rainfall pattern. Rainfall that is timely and enough is critical for small agricultural communities' livelihoods and food security [15]. The impact of adequate groundwater supply is important in certain countries, such as the West Africa sub-region, where agriculture employs more than $80 \%$ of the people $[15,16]$.

The importance of timely rainfall to the whole economy cannot be overstated. However, rainfall in Africa varies dramatically on an annual, decadal, and longer time scale [17]. Senegal, Mali, Burkina Faso, Niger, Nigeria, Chad, Sudan, Ethiopia, Somalia, Kenya, Tanzania, Zambia, Malawi, Mozambique, Zimbabwe, and South Africa account for the majority of Africa's 100 million people living in water-stressed rain-fed agriculture [18].

\section{Materials and Methods}

This study did an exploratory literature review of selected case studies of watershed management in Africa and also explore a comparative analysis of the watershed/catchment and river basins in Africa. With the emphasis on groundwater resources distribution of the sixteen countries in Western Africa (Benin, Burkina Faso, Cape Verde, Côte d'Ivoire, Gambia, Ghana, Guinea, Guinea-Bissau, Liberia, Mali, Mauritania, Niger, Nigeria, Senegal, Sierra Leone, and Togo). 
It captures data within the worldview of the other regions like; Northern Africa (Algeria, Egypt, Libyan Arab Jamahiriya, Morocco, Sudan, Tunisia), Eastern Africa (Burundi, Djibouti, Eritrea, Ethiopia, Kenya, Rwanda, Somalia, Uganda), Central Africa (Cameroon, Central African Republic, Chad, Congo, Democratic Republic of Congo, Equatorial Guinea, Gabon, Sao Tomé and Principe), Southern Africa (Angola, Botswana, Lesotho, Malawi, Mozambique, Namibia, South Africa, Swaziland, United Republic of Tanzania, Cairo, Zambia, Zimbabwe) and The Western Indian Ocean Islands (Comoros, Madagascar, Mauritius, Seychelles). While emphasizing the Integrated Watershed Management (IWM) and the characteristics of groundwater resources in Africa shared watersheds and river basins in line with the following sub-themes: the multitude of shared watercourses, most countries share at least one watercourse with neighbours up to 14 shared watercourses in guinea alone, about 80 watershed basins in Africa, major basins: 20 major river/lake basins. Covering $60 \%(18,000,000 \mathrm{~km})$ of landmass), about $395 \mathrm{~m}$ people (45 \% of the population) live within the catchments of the basins [19].

\subsection{Study Area: Africa (West Africa)}

Hydrologists use data sets on precipitation, temperature, evapotranspiration, terrain, soils, and man-made diversions and impoundments to simulate Africa's surface water systems. Recent study has employed satellite data to more precisely characterize land-surface processes across the African continent, allowing for more accurate estimates of vegetation water usage. This provides a map of "evapotranspiration," which is an estimate of the total of surface evaporation and plant transpiration, when combined with climatic data. As illustrated in Figure 2, this data layer was utilized to more precisely construct a water balance map (rainfall minus evapotranspiration). This water-balance map is used to simulate surface water and groundwater behavior, as well as stream flow and the possibility for dams and other water harvesting methods. Africa's geology and climate, which includes periodic drought and extremely variable rainfall, are neither the only nor even the most significant factors contributing to the continent's water shortage. Growing populations, together with growing water use, rising water costs, and limited water supplies, exacerbate the situation.

A tendency toward urbanization and greater living standards, poor or no city planning, a shortage of resources, and rivalry for available freshwater across sectors such as industry, municipal water, and agriculture, as well as between nations that share watercourses, all limit water supply. Water stress or shortage has developed in the region, where the amount and quality of water may not be sufficient to provide clean drinking water, food, and hygiene, may stifle economic development, and severely limit environmental resources. As a result of these problems, individuals lack access to safe drinking water and sufficient sanitary facilities [20]. Africa also has some of the world's largest natural and man-made lakes, as well as dams. Africa's natural lakes and dams have a total capacity that is twenty times greater than Latin America's [21]. Lake Victoria is the world's second-largest freshwater lake, with an area of around 68,600 km2. Despite its shallowness, it is the world's second-largest freshwater lake [22]. 


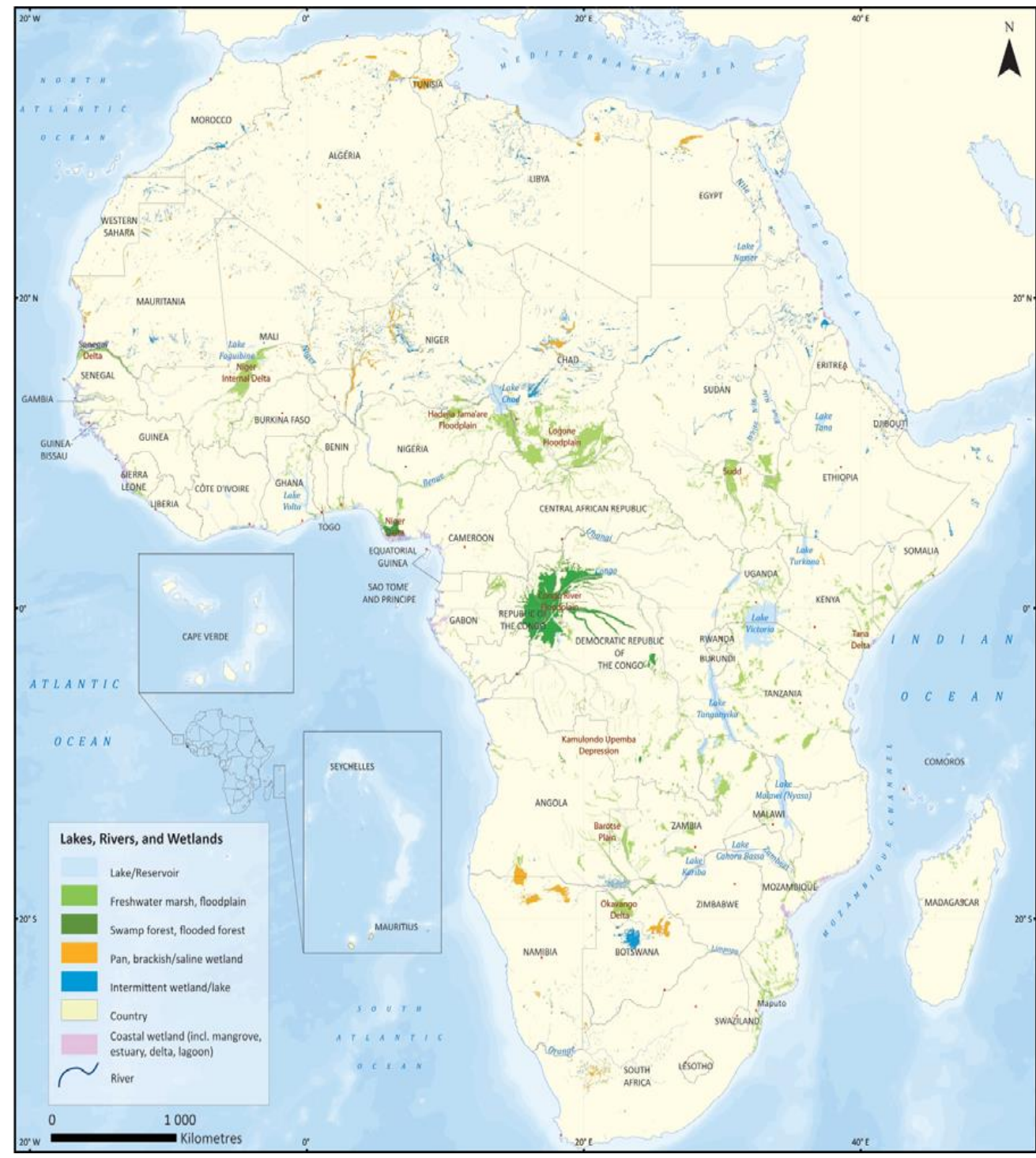

Figure 2: Map showing the Surface water, natural lakes, rivers, and wetlands (Source: UNEP-WCMC 2006).

Lake Chad is Africa's shallowest major lake and the continents fourth-biggest by surface area; it is also the Sahel's largest wetland. The Lake Chad basin is the world's biggest endorheic basin (a region with terminal lakes and an interior drainage basin) with a surface area of 2,500,000km2 [23]. Lake Chad had a surface size of around 25,000 kilometers in the 1960s, but it shrank rapidly in the early 1970s and has since fluctuated between 2,000 and 15,000 kilometers, depending on the season [24]. A combination of severe droughts and agricultural water exploitation has caused the area to decline significantly since the 1960s [25]. Natural lakes in Africa come from a variety of places. Lakes Malawi, Albert, Tanganyika, and Turkana are deep tectonic lakes in the East African Rift Valley; other lakes, such as Lake Kivu in the Rwanda/Democratic Republic of the Congo, were produced by volcanic activity. Shallow floodplain lakes, such as those seen in the Okavango Swamps, are also present. There are several soda lakes in the East African Rift Valley, as well as deflation basins or pans like those seen in the Kalahari and Pinelands of

South Africa. In addition, Africa features several high-altitude glacial lakes [24].

Africa's lakes support major fisheries that provide jobs for millions of people and help to ensure food security. Africa is second only to Asia in the worldwide capture of inland fish, with Uganda, the United Republic of Tanzania, Egypt, Kenya, and the Democratic Republic of the Congo among its significant inland fishing nations [26]. As 
illustrated in Figure 2, Africa has 63 shared basins that encompass over $64 \%$ of the continent [26].

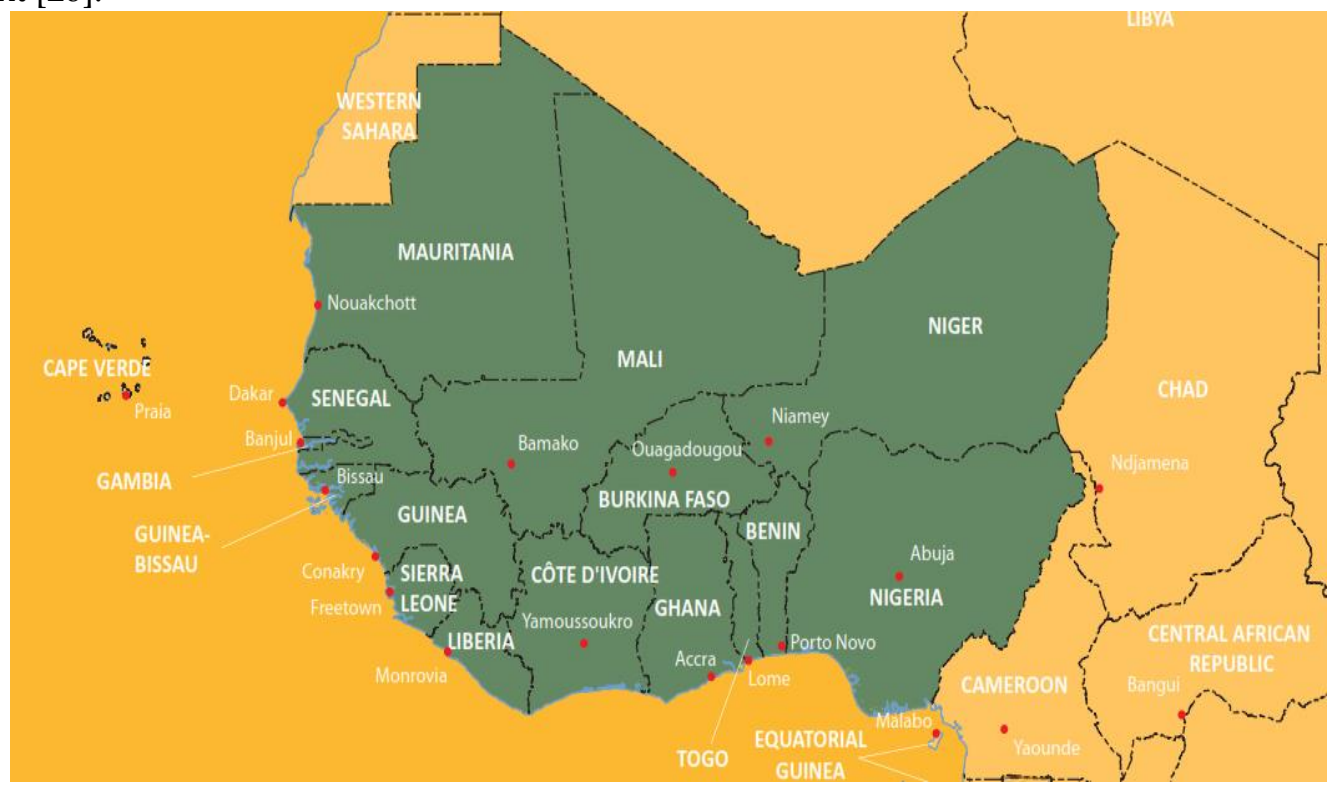

Figure 3: Map showing the sixteen countries of the Africa Sub-region.

Table 2: Table showing the thirteen (13) selected key locations of Watershed/Catchment and River Basins in Africa.

\begin{tabular}{|c|c|c|c|}
\hline $\begin{array}{l}\text { Key } \\
\text { Locations }\end{array}$ & $\begin{array}{l}\text { Raster Imagery of the } \\
\text { Location }\end{array}$ & $\begin{array}{l}\text { Position within } \\
\text { Africa's Worldview }\end{array}$ & Remarks \\
\hline $\begin{array}{l}\text { Congo } \\
\text { River Basin }\end{array}$ & & & $\begin{array}{l}\text { The Congo Basin is a massive 3,700,000 } \\
\mathrm{km} \text { depression that stretches almost } 2000 \\
\mathrm{~km} \text { north-south and east-west. It spans the } \\
\text { equator and collects a lot of rain, which } \\
\text { falls on the tropical rainforests that cover } \\
\text { much of its surface. }\end{array}$ \\
\hline $\begin{array}{l}\text { Juba Shabelle } \\
\text { Basin }\end{array}$ & 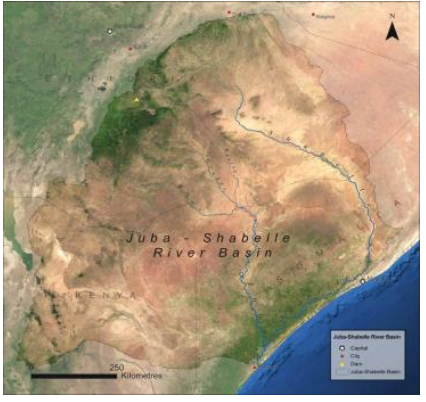 & & $\begin{array}{l}\text { Both the Juba and the Shabelle have their } \\
\text { origins in the southern Ethiopian } \\
\text { Highlands, at a height of nearly } 3000 \\
\text { meters above sea level. Although the Juba } \\
\text { has a smaller catchment area, it receives } \\
\text { more rain and has much more runoff } \\
\text { around its headwaters. }\end{array}$ \\
\hline $\begin{array}{l}\text { Lake Chad } \\
\text { Basin }\end{array}$ & & & $\begin{array}{l}\text { The Lake Chad drainage basin covers little } \\
\text { over } 8 \% \text { of Africa's surface area and is } \\
\text { shared by eight countries: Algeria, } \\
\text { Cameroon, Central African Republic, } \\
\text { Chad, Libya, Niger, Nigeria, and Sudan. }\end{array}$ \\
\hline
\end{tabular}




\begin{tabular}{|c|c|c|}
\hline $\begin{array}{l}\text { Lake Turkana } \\
\text { Basin }\end{array}$ & & $\begin{array}{l}\text { Even though the Lake Turkana Basin } \\
\text { spans four nations, just two of them } \\
\text { account for } 98 \text { percent of its total area. } \\
\text { Ethiopia, which receives about } \\
\text { three-quarters of the basin's rainfall, } \\
\text { accounts for more than half ( } 52 \text { percent). }\end{array}$ \\
\hline $\begin{array}{l}\text { Limpopo } \\
\text { River Basin }\end{array}$ & & $\begin{array}{l}\text { The mostly semi-arid Limpopo River } \\
\text { watershed receives the majority of its } \\
\text { precipitation during a brief, strong rainy } \\
\text { season in the austral summer (December- } \\
\text { February). Rainfall varies greatly } \\
\text { throughout the year and across seasons, } \\
\text { rendering the basin vulnerable to severe } \\
\text { drought and flooding. }\end{array}$ \\
\hline $\begin{array}{l}\text { Niger } \\
\text { River Basin }\end{array}$ & $\because=$ & $\begin{array}{l}\text { The Niger River originates in eastern } \\
\text { Guinea's Fouta Djallon mountains and } \\
\text { Côte d'Ivoire's extreme northwestern } \\
\text { corner. The mean annual precipitation is } \\
\text { the heaviest in the basin, with } 1,635 \\
\mathrm{~mm} / \mathrm{yr} \text { in Guinea and 1,466 mm/yr in Côte } \\
\text { d'Ivoire [27]. }\end{array}$ \\
\hline $\begin{array}{l}\text { Nile } \\
\text { River Basin }\end{array}$ & & $\begin{array}{l}\text { In northern Burundi, the Nile begins its } \\
6-800 \text {-kilometer trek to the sea at } 1,600 \\
\text { meters above sea level. The Mara, Nzoia, } \\
\text { Katonga, Kagera, Yala, Isanga, Sondu, } \\
\text { Ruizi, Kibos, Simiyu, and Sio are among } \\
\text { the many rivers that pour into Lake } \\
\text { Victoria; however, only the Victoria Nile } \\
\text { flows out. }\end{array}$ \\
\hline $\begin{array}{l}\text { Ogooué } \\
\text { River Basin }\end{array}$ & & $\begin{array}{l}\text { The Ogooué River rises near Gabon's } \\
\text { border at a relatively low height. } \\
\text { Approximately } 85 \text { percent of the basin is } \\
\text { located in Gabon, with the remaining } 12 \\
\text { percent in Congo and Cameroon, and } \\
\text { Equatorial Guinea. A thick network of } \\
\text { perennial streams feeds the river. }\end{array}$ \\
\hline
\end{tabular}




\begin{tabular}{|c|c|c|}
\hline $\begin{array}{l}\text { Okavango } \\
\text { Delta } \\
\text { Makgadikgad } \\
\text { i Basin }\end{array}$ & 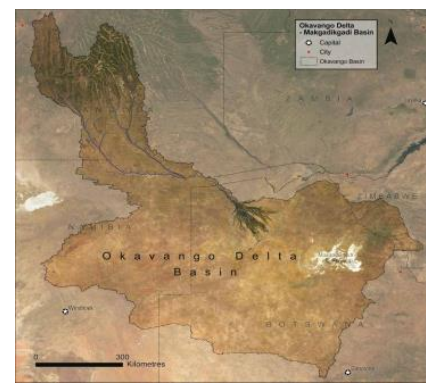 & $\begin{array}{l}\text { The Okavango Delta Basin is a } \\
\text { sub-catchment of the larger Makgadikgadi } \\
\text { Salt Pans drainage basin. However, the } \\
\text { pans are only flooded periodically, and } \\
\text { the Okavango system contains the } \\
\text { majority of the basin's water supplies. }\end{array}$ \\
\hline $\begin{array}{l}\text { Orange } \\
\text { River Basin }\end{array}$ & & $\begin{array}{l}\text { The Orange River begins high in the } \\
\text { Drakensberg Mountains in Lesotho, where } \\
\text { its tributary, the Senqu, begins. Despite } \\
\text { accounting for only } 3 \% \text { of the basin, } \\
\text { Lesotho's mountains get some of the } \\
\text { greatest mean annual rainfall in the basin, } \\
\text { and Lesotho supplies almost } 17 \% \text { of the } \\
\text { Orange River's water budget. }\end{array}$ \\
\hline $\begin{array}{l}\text { Senegal } \\
\text { River Basin }\end{array}$ & & $\begin{array}{l}\text { The Bafing and Bakoye Rivers, both of } \\
\text { which originate in the Guinea Highlands, } \\
\text { are the Senegal River's two main } \\
\text { tributaries. The Bafi River, which starts at } \\
800 \text { meters in the Fouta Djallon, is the } \\
\text { source of the majority of Senegal's flow. } \\
\text { The Bakoye originates around } 250 \\
\text { kilometers to the east, on the Manding } \\
\text { Plateau. }\end{array}$ \\
\hline $\begin{array}{l}\text { Volta } \\
\text { River Basin }\end{array}$ & & $\begin{array}{l}\text { The Volta Basin spans sections of six West } \\
\text { African countries. Burkina Faso and } \\
\text { Ghana account for around } 40 \% \text { of the } \\
\text { basin's total area. Togo accounts for } 8 \% \text { of } \\
\text { the total, while Benin, Côte d'Ivoire, and } \\
\text { Mali account for the remaining } 12 \% \text {. }\end{array}$ \\
\hline $\begin{array}{l}\text { Zambezi } \\
\text { River Basin }\end{array}$ & & $\begin{array}{l}\text { The Zambezi River starts in the Kalene } \\
\text { Hills, about } 1200 \text { meters above sea level, } \\
\text { where the borders of eastern Angola, } \\
\text { northern Zambia, and southern DRC } \\
\text { meet. Miombo woods with networks of } \\
\text { grassy wetlands along drainage lines and } \\
\text { riverine forests along bigger streams } \\
\text { dominate the terrain as it travels through } \\
\text { Angola and northeastern Zambia. }\end{array}$ \\
\hline
\end{tabular}

Source: Partly adapted and modified from UNEP (2010). "Africa Water Atlas". An article by the Division of Early Warning and Assessment (DEWA) and the United Nations Environment Programme (UNEP), Nairobi, Kenya. 
Due to the lack of roads in many sections of the Congo Basin, transportation along the river's navigable channels is critical for commercial activity, as seen in the table above in the order of arrangement. Shabelle's discharge usually ends up in marshes just before it meets the Juba in most years. Lake Turkana is the world's biggest desert lake, while Lake Chad is one of the Sahel's greatest freshwater reservoirs. Irrigation is unreliable due to Limpopo's unpredictable streamflow. In the arid Sahel, the Niger River provides a lush oasis of life and greenery. The Nile is vital to about 78 million Egyptians [26].

Table 2 revealed that the Congo Basin is a vast 3,700,000-square-kilometer depression that runs over 2000 kilometers north-south and east-west. It stretches across the equator and accumulates a lot of rain, which falls on the tropical rainforests that cover a large portion of its surface. While Algeria, Cameroon, Central African Republic, Chad, Libya, Niger, Nigeria, and Sudan are all part of the Lake Chad drainage basin, which encompasses little over $8 \%$ of Africa's surface area.

The population of the basins are largely centered around river systems in the region. There are no big dams or substantial water diversions on the Okavango's tributaries. Lesotho's highlands produce almost 17 percent of the basin's water budget, although accounting for only 3\% of the basin's total area. Because of the river's transboundary character, managing the water resources of the Senegal River Basin is complicated. The Volta Basin spans sections of six West African countries. The Zambezi basin is home to more than 40 million people [26].

Table 3: Table showing the Water Profile in the Sixteen Countries in West Africa sector (Average Water Profiling from the year 2000-2021).

\begin{tabular}{|l|l|l|l|}
\hline Country & $\begin{array}{l}\text { Total Surface } \\
\text { Area Km2 (Ha) }\end{array}$ & $\begin{array}{l}\text { Average } \\
\text { Precipitation } \\
\text { in } \\
(\mathbf{m m} / \mathbf{y r})\end{array}$ & Water Resource and Watershed Challenges \\
\hline $\begin{array}{l}\text { The Federal } \\
\text { Republic of } \\
\text { Nigeria }\end{array}$ & $\begin{array}{l}923,768 \mathrm{~km} 2 \\
91,077 \mathrm{ha}\end{array}$ & 1,150 & $\begin{array}{l}\text { Fadama regions, which are low-lying areas inundated } \\
\text { during the rainy season, are found throughout most of the } \\
\text { nation, including the Guinea Savannah, Sudan Savannah, } \\
\text { and Sahel natural zones. }\end{array}$ \\
\hline $\begin{array}{l}\text { Islamic } \\
\text { Republic of }\end{array}$ & $\begin{array}{l}(1,025,520 \mathrm{~km} 2 \\
\text { Mauritania }\end{array}$ & 92 & $\begin{array}{l}\text { Since Mauritania is surrounded by deserts and experiences } \\
\text { periodic droughts, water is inherently scarce. The building } \\
\text { of two new dams on the Senegal River has aided the fast } \\
\text { expansion of Mauritania's irrigated agriculture sector. }\end{array}$ \\
\hline $\begin{array}{l}\text { Republic of } \\
\text { Benin }\end{array}$ & $\begin{array}{l}112,622 \mathrm{~km} 2 \\
(11,063 \mathrm{ha})\end{array}$ & 1,039 & $\begin{array}{l}\text { Water resources are unevenly allocated both geographically } \\
\text { and through time, although enough water is available for } \\
\text { present and future requirements. }\end{array}$ \\
\hline $\begin{array}{l}\text { Burkina Faso } \\
274,000 \mathrm{~km} 2 \\
(27,360 \mathrm{ha})\end{array}$ & $\begin{array}{l}\text { Burkina Faso is located in the Sahel, where droughts and } \\
\text { floods are becoming increasingly frequent and severe. } \\
\text { Rain-fed agriculture is being phased out, and people are }\end{array}$ \\
\hline
\end{tabular}




\begin{tabular}{|c|c|c|c|}
\hline & & & flocking to peri-urban regions. \\
\hline $\begin{array}{l}\text { Republic of } \\
\text { Cabo Verde }\end{array}$ & $\begin{array}{l}4,033 \mathrm{~km} 2 \\
(433 \mathrm{ha})\end{array}$ & 228 & $\begin{array}{l}\text { Cape Verde has limited rainfall and is subject to severe } \\
\text { droughts on occasion, limiting water supplies. Aquifers } \\
\text { along the shore have been overexploited, resulting in well } \\
\text { seawater intrusion. }\end{array}$ \\
\hline $\begin{array}{l}\text { Republic of } \\
\text { Côte d'Ivoire }\end{array}$ & $\begin{array}{l}322,463 \mathrm{~km} 2 \\
(31,800 \mathrm{ha})\end{array}$ & 1,348 & $\begin{array}{l}\text { Chemical waste from agricultural, industrial, and mining } \\
\text { sources has resulted in considerable water contamination in } \\
\text { Côte d'Ivoire. }\end{array}$ \\
\hline $\begin{array}{l}\text { Republic of } \\
\text { Ghana }\end{array}$ & $\begin{array}{l}238,553 \mathrm{~km} 2 \\
(22,754 \mathrm{ha}) \\
\end{array}$ & 1,187 & $\begin{array}{l}\text { In Ghana, water reforms have made significant progress, } \\
\text { increasing from } 54 \text { percent in } 1990 \text { to } 80 \text { percent in } 2008 \text {. }\end{array}$ \\
\hline $\begin{array}{l}\text { Republic of } \\
\text { Guinea }\end{array}$ & $\begin{array}{l}245,857 \mathrm{~km} 2 \\
(24,572 \mathrm{ha})\end{array}$ & 1,651 & $\begin{array}{l}\text { Guinea is one of the wettest countries in West Africa, yet } \\
\text { water treatment plants regularly fail, leaving the country } \\
\text { without flowing water for weeks. }\end{array}$ \\
\hline $\begin{array}{l}\text { Republic of } \\
\text { Guinea-Bissau }\end{array}$ & $\begin{array}{l}36,125 \mathrm{~km} 2 \\
(3,612 \mathrm{ha})\end{array}$ & 1,577 & $\begin{array}{l}\text { The water and sanitation infrastructure of Guinea-Bissau is } \\
\text { among the worst in the world. The bulk of the population } \\
\text { relies on shallow wells, which are frequently polluted by } \\
\text { sanitary facilities nearby. }\end{array}$ \\
\hline $\begin{array}{l}\text { Republic of } \\
\text { Liberia }\end{array}$ & $\begin{array}{l}111,369 \mathrm{~km} 2 \\
(11,137 \mathrm{ha})\end{array}$ & 2,391 & $\begin{array}{l}\text { The nearby wetlands are a valuable resource for the } \\
\text { community. Residents of Liberia have complained of } \\
\text { diarrhoea as a result of drinking the water. }\end{array}$ \\
\hline $\begin{array}{l}\text { Republic of } \\
\text { Mali }\end{array}$ & $\begin{array}{l}1,240,192 \mathrm{~km} 2 \\
(122,019 \mathrm{ha})\end{array}$ & 282 & $\begin{array}{l}\text { Droughts and desertification are becoming more of a } \\
\text { danger to Mali's ecosystems and livelihoods. Mali is a } \\
\text { landlocked country in western Africa. }\end{array}$ \\
\hline $\begin{array}{l}\text { Republic of } \\
\text { Niger }\end{array}$ & $\begin{array}{l}1,267,000 \mathrm{~km} 2 \\
(126,670 \mathrm{ha})\end{array}$ & 151 & $\begin{array}{l}\text { Only a small fraction of Niger's land is arable due to its dry } \\
\text { environment and the fact that } 65 \text { percent of its area is } \\
\text { within the Sahara Desert. }\end{array}$ \\
\hline $\begin{array}{l}\text { Republic of } \\
\text { Senegal }\end{array}$ & $\begin{array}{l}196,722 \mathrm{~km} 2 \\
19,252 \text { ha }\end{array}$ & 686 & $\begin{array}{l}\text { Guinea, Mali, Mauritania, and Senegal are all riparian } \\
\text { nations along the 1,800-kilometer Senegal River. Dam } \\
\text { development, on the other hand, has put this crucial } \\
\text { ecosystem in jeopardy, resulting in environmental } \\
\text { deterioration and detrimental effects on residents' health. }\end{array}$ \\
\hline $\begin{array}{l}\text { Republic of } \\
\text { Sierra Leone }\end{array}$ & $\begin{array}{l}71,740 \mathrm{~km} 2 \\
(7,162 \mathrm{ha})\end{array}$ & 2,526 & $\begin{array}{l}\text { Notwithstanding the economic benefits, hydropower } \\
\text { expansion frequently puts riparian populations' homes and } \\
\text { livelihoods at risk. }\end{array}$ \\
\hline $\begin{array}{l}\text { Republic of } \\
\text { The Gambia }\end{array}$ & $\begin{array}{l}11,295 \mathrm{~km} 2 \\
(1,290 \mathrm{ha})\end{array}$ & 836 & $\begin{array}{l}\text { Gambia's whole nation sits within the Gambia River's } \\
\text { drainage basin, which has a highly seasonal flow. The } \\
\text { salinity of the ocean has an impact on the Gambia's } \\
\text { lowlands, which has a significant impact on the country's } \\
\text { flora and water consumption. }\end{array}$ \\
\hline $\begin{array}{l}\text { Togolese } \\
\text { Republic }\end{array}$ & $\begin{array}{l}56,785 \mathrm{~km} 2 \\
(5,439 \mathrm{ha})\end{array}$ & 1,168 & $\begin{array}{l}\text { Togo is vulnerable to sea-level rises due to its relatively flat } \\
\text { geography and large coastline zone }(1,710 \mathrm{~km}) \text {. }\end{array}$ \\
\hline
\end{tabular}




\begin{tabular}{|l|l|l|l|}
\hline Total & $\begin{array}{l}(6,138,044 \mathrm{~km} 2) \\
733,359 \text { ha }\end{array}$ & $17,060 \mathrm{~mm} / \mathrm{yr}$ & \\
\hline
\end{tabular}

Table 3 clearly shows average precipitation of $17,060 \mathrm{~mm} / \mathrm{yr}$ per year over $733,359 \mathrm{ha}$ of land with the Republic of Sierra Leone recording the highest having a land cover of $71,740 \mathrm{~km} 2$ (7,162ha) and 2,526mm/yr per annum. The Islamic Republic of Mauritania despite having the third-largest land surface area of 1,025,520km2 (102,522ha) 92mm/yr per annum.

Table 4: Table showing the groundwater resources usage in West Africa (average water withdrawal from 2000-2021).

\begin{tabular}{|c|c|c|c|c|}
\hline Countries & Municipal & Industrial & Agricultural & Remarks \\
\hline $\begin{array}{l}\text { Federal Republic of } \\
\text { Nigeria }\end{array}$ & $21.1 \%$ & $10.1 \%$ & $68.8 \%$ & Generally adequate for agricultural purposes \\
\hline $\begin{array}{l}\text { Islamic Republic of } \\
\text { Mauritania }\end{array}$ & $8.9 \%$ & $2.9 \%$ & $88.2 \%$ & Generally adequate for agricultural purposes \\
\hline $\begin{array}{l}\text { Republic of } \\
\text { Benin }\end{array}$ & $31.5 \%$ & $23.1 \%$ & $45.4 \%$ & $\begin{array}{l}\text { Generally inadequate for agricultural } \\
\text { purposes }\end{array}$ \\
\hline Burkina Faso & $13 \%$ & $0.8 \%$ & $86.2 \%$ & Generally adequate for agricultural purposes \\
\hline $\begin{array}{l}\text { Republic of } \\
\text { Cabo Verde }\end{array}$ & $7.3 \%$ & $1.8 \%$ & $90.9 \%$ & Generally adequate for agricultural purposes \\
\hline $\begin{array}{l}\text { Republic of } \\
\text { Côte d'Ivoire }\end{array}$ & $23.7 \%$ & $11.4 \%$ & $64.5 \%$ & Fairly adequate for agricultural purposes \\
\hline $\begin{array}{l}\text { Republic of } \\
\text { Ghana }\end{array}$ & $23.9 \%$ & $9.7 \%$ & $66.4 \%$ & Fairly adequate for agricultural purposes \\
\hline $\begin{array}{l}\text { Republic of } \\
\text { Guinea }\end{array}$ & $7.9 \%$ & $1.9 \%$ & $90.1 \%$ & Generally adequate for agricultural purposes \\
\hline $\begin{array}{l}\text { Republic of } \\
\text { Guinea-Bissau }\end{array}$ & $13.1 \%$ & $4.6 \%$ & $82.3 \%$ & Generally adequate for agricultural purposes \\
\hline $\begin{array}{l}\text { Republic of } \\
\text { Liberia }\end{array}$ & $27.2 \%$ & $18.2 \%$ & $54.6 \%$ & Fairly adequate for agricultural purposes \\
\hline $\begin{array}{l}\text { Republic of } \\
\text { Mali }\end{array}$ & $9 \%$ & $0.9 \%$ & $90.1 \%$ & Generally adequate for agricultural purposes \\
\hline $\begin{array}{l}\text { Republic of } \\
\text { Niger }\end{array}$ & $4.1 \%$ & $0.5 \%$ & $95.4 \%$ & Generally adequate for agricultural purposes \\
\hline $\begin{array}{l}\text { Republic of } \\
\text { Senegal }\end{array}$ & $4.5 \%$ & $2.6 \%$ & $92.9 \%$ & Generally adequate for agricultural purposes \\
\hline $\begin{array}{l}\text { Republic of } \\
\text { Sierra Leone }\end{array}$ & $5.3 \%$ & $2.6 \%$ & $92.1 \%$ & Generally adequate for agricultural purposes \\
\hline $\begin{array}{l}\text { Republic of } \\
\text { The Gambia }\end{array}$ & $22.9 \%$ & $11.8 \%$ & $65.3 \%$ & Fairly adequate for agricultural purposes \\
\hline Togolese Republic & $52.7 \%$ & $2.4 \%$ & $44.9 \%$ & $\begin{array}{l}\text { Generally inadequate for agricultural } \\
\text { purposes. }\end{array}$ \\
\hline
\end{tabular}


Source: Partly adapted and modified from "Water Atlas of Africa" (2010). Early Warning and Assessment Division (DEWA). UN Environment Programme (UNEP).

The Republic of Niger recorded the highest consumption of groundwater (95.4\%) for agricultural use, the Republic of Benin recorded the highest for industrial use while the Togolese Republic is top in the chart for the consumption within the city and suburb (see table 4).

\section{Discussion}

In Africa, river basins and groundwater are critical for municipal, industrial, and agricultural purposes, particularly in the arid northern and southern sub-regions. Groundwater is widespread but restricted, accounting for just $15 \%$ of the continent's renewable water resources yet providing drinking water to three-quarters of the continent's population [26]. Lusaka, Windhoek, Kampala, Addis Ababa, and Cairo rely heavily on groundwater for municipal water, and groundwater also helps to feed other cities including Lagos, Abidjan, Cape Town, and Pretoria [28]. Groundwater is a vital source of water for people and animals in rural areas of Africa, and it is quickly becoming the only realistic way to satisfy the demands of rural communities in the continent's dry and semiarid regions [28].

Many countries rely on foreign contributions to their renewable water resources due to a large number of transboundary water basins. Egypt (97 percent), Mauritania (97 percent), Niger (90 percent), Botswana (80 percent), Sudan (77 percent), and Congo (77 percent) are also highly reliant countries (73 percent). Furthermore, it was revealed that the bulk of water basins are not shared by neighbouring nations. The Nile, Zambezi, Congo, Niger, Senegal, Lake Victoria, and Lake Chad are among the major river basin organizations (RBOs) that have been founded, and these organizations confront a variety of issues. There are also some bilateral agreements between some of the countries that cannot be proven. The 1997 UN Convention on non-navigational uses of international watercourses is yet to be signed or implemented by any African country [29].

The findings of this study (see table 2, $3 \& 4$ ) are based on the literature on watershed and groundwater resource management approaches that suggested integrating technologies within the natural boundaries of a drainage area for optimal land, water, and plant resource development to meet the basic needs of people and animals sustainably. Integrated watershed management proposes land and water conservation practices, water harvesting in ponds, and groundwater recharging to increase water resources potential and stress on crop diversilcation, improved seed varieties, integrated nutrient management, and integrated pest management practices to achieve its goal. Watershed and groundwater management necessitates diverse skills and competencies; the strategic community engagement model comprises main stakeholders, government and non-government organizations, and other institutions. The observed outstanding results on the runoffs are mostly due to easy access and quick advice to farmers.

\subsection{What are the Watershed and Water Resources Management Issues?}

In Africa, four major concerns impact the management of watersheds, river/catchment basins, and groundwater resources, as shown in Table 5. Finance, human capacity and a lack of data inadequate water access for various purposes, ecological habitat loss, and biodiversity loss.

Table 5: Table showing the major concerns and issues regarding IWM.

\begin{tabular}{|l|l|}
\hline Finance & a. The majority of African nations are unable to establish viable institutional frameworks \\
\hline
\end{tabular}




\begin{tabular}{|c|c|}
\hline & $\begin{array}{l}\text { and invest enough in the water sector. } \\
\text { b. Raising public knowledge of Integrated Watershed Resource Management (IWRM) } \\
\text { and gaining political support for it. } \\
\text { c. Several water-related initiatives, programs, and projects are being developed and/or } \\
\text { supported by continental and regional organizations. } \\
\text { d. Water policy changes are ongoing in most nations, with a focus on decentralization, } \\
\text { stakeholder engagement, and transparency (PPP). } \\
\text { e. Donors, multilateral organizations, and international development banks should in- } \\
\text { crease their assistance and investment. }\end{array}$ \\
\hline $\begin{array}{l}\text { Lack of Data and } \\
\text { Human Capacity }\end{array}$ & $\begin{array}{l}\text { a. A scarcity of accurate and trustworthy facts. } \\
\text { b. Advocacy for adequate data collection and administration must be robust, effective, } \\
\text { and long-term. } \\
\text { c. Africa has a scarcity of IWRM talents. } \\
\text { d. The Global Water Partnership's (GWP) efforts to raise knowledge and sensitize people } \\
\text { about IWRM concepts. } \\
\text { e. Strengthening IWRM capabilities through regional and national collaborations, as well } \\
\text { as regional capacity-building networks. } \\
\text { f. National, regional, and continental organizations and initiatives should join and } \\
\text { support these relationships and networks. }\end{array}$ \\
\hline $\begin{array}{l}\text { Inadequate Access } \\
\text { to Water for Vari- } \\
\text { ous Purposes }\end{array}$ & $\begin{array}{l}\text { a. It is critical to increase investment in water supply and sanitation to break the vicious } \\
\text { cycle of poverty and insufficient water supply and sanitation (a necessity for attaining } \\
\text { most of the MDGs). } \\
\text { b. Irrigation is used on less than } 5 \% \text { of agricultural land in most African nations. } \\
\text { c. Food insecurity increased from } 125 \text { million in } 1980 \text { to } 200 \text { million in } 2000 \text { in } \\
\text { Sub-Saharan Africa, with an average daily per capita food supply of only } 2,200 \mathrm{kcal} \\
\text { (global average of 2,800 kcal). } \\
\text { d. To meet the SDGs' food security objective, irrigated lands must be increased by more } \\
\text { than } 5 \text { times. }>90 \% \text { of Africa's population lacks access to power. } \\
\text { e. With } 950 \mathrm{kWh} \text { per capita, Botswana is the country with the highest per capita usage. } \\
\text { This is significantly less than the global weighted average per capita of } 2750 \mathrm{kWh} \text {. }\end{array}$ \\
\hline $\begin{array}{l}\text { Loss of Ecological } \\
\text { Habitats and Loss } \\
\text { of Biodiversity }\end{array}$ & $\begin{array}{l}\text { The following are some of the negative consequences of improperly developed and } \\
\text { managed water resources infrastructures: } \\
\text { a. Loss of unique habitats and biodiversity. } \\
\text { b. Reduced flood retention capacity, pollution of water sources, and changes in micro- } \\
\text { climate regulation groundwater levels are rapidly declining in some places. } \\
\text { c. Large-scale irrigation schemes are causing salinization of the soil and creating water- } \\
\text { logged conditions, thereby reducing the productive potentials of the sowing season. }\end{array}$ \\
\hline
\end{tabular}

\section{Conclusions}

This study outlined the key issues of watershed and groundwater resource management and development in Africa, which stem from poor river basin management, which results in limited access, destructive erosion, wildfires, flooding, persistent drought, and desertification, particularly in the north. Continuous use and deterioration of watersheds, rivers, lakes, and other linked watercourses bring these challenges to the forefront. With countries recording high precipitation while others are recording low as the study indicates an average annual precipitation of $17,060 \mathrm{~mm}$ over 733,359 ha of land, with the Republic of Sierra Leone recording the highest of 2,526 mm/yr while the Islamic Republic of Mauritania receives $92 \mathrm{~mm} / \mathrm{yr}$ each year. Lack of organized water resources regulations and development master plans, old data (if available), civil conflict, and disputes along international seas are also factors to consider. Sustainable watershed and groundwater resource management, on the other hand, necessitates a well-organized and well-coordinated structure including all important stakeholders, as well as an institutional framework designed to produce beneficial results. 
The following suggestions were made in this paper:

a. Create a framework for simplifying and building synergies between national, regional, and intercontinental activities aimed at maximizing the effectiveness and sustainability of Africa's existing waterways and natural resources.

b. Slowing the rate of urbanization and population increase near river basins; $c$. Water infrastructure investment using contemporary technologies;

c. Experts and human resources providing up-to-date data to counteract misuse;

d. Cooperation among nations sharing water basins and strict adherence by all African countries to the 1997 UN Convention on Non-navigational Uses of International Watercourses.

By 2030, there will be sustainable and strategic IWRM strategies as well as water safety measures. There should be mutual understanding and synergies between initiatives, programs, and projects at the national, regional, and continental levels. The current state of integrated watershed management, river basin frameworks, and groundwater resources requires a comprehensive, community, and multidisciplinary approach.

Every region (the six regions; Western, Eastern, Central, Northern, Southern, and The Western Indian Ocean Islands) of the Africa continent must consider natural as well as human resources, coordinated developmental approach towards a sustainable watershed and groundwater resources management.

Author Contributions: A.A.J. prepared the planning, conceptualization, methodology and writing of the manuscript. J.J. and T. X. both reviewed and revised the manuscript to this present form. A.A.J., J.J. and T.X. have all read and agreed to the published version of the manuscript.

Funding: This research received no external funding.

Data Availability Statement: Africa Water Atlas by United Nations Environment Programme, Volume 1 https://na.unep.net/atlas/africawater/downloads/chapters/africa_water_atlas_37122.pdf. https://books.google.com.ng/books.

Acknowledgements: The authors will like to appreciate the College of International Education, Nanjing Forestry University, Nanjing, China for the time given to put this article together.

Conflicts of Interest: The authors declare no conflict of interest.

\section{References}

1. Patle, D., Rao, J. H., \& Dubey, S. (2020). Morphometric analysis and prioritization of sub-watersheds in Nahra watershed of Balaghat district, Madhya Pradesh: A remote sensing and GIS perspective. Journal of Experimental Biology and Agricultural Sciences, $8(4)$, 447-455. https://www.researchgate.net/publication/343994020_MORPHOMETRIC_ANALYSIS_AND_PRIORITIZATION_OF_SU B-WATERSHEDS_IN_NAHRA_WATERSHED_OF_BALAGHAT_DISTRICT_MADHYA_PRADESH_A_REMOTE_SENS ING_AND_GIS_PERSPECTIVE.

2. United Nations Environment Programme. Division of Environmental Law, \& Conventions. (2007). Glossary of terms for negotiators of multilateral environmental agreements. UNEP/Earth print. https://www.unep.org/resources/report/glossary-terms-negotiators-multilateral-environmental-agreements.

3. Heathcote, I. W. (2009). Integrated watershed management: principles and practice. John Wiley \& Sons.

4. Pavelic, P., Brindha, K., Amarnath, G., Eriyagama, N., Muthuwatta, L., Smakhtin, V., ... \& Kant, L. (2015). Controlling floods and droughts through underground storage: From concept to pilot implementation in the Ganges River Basin (Vol. 165). International Water Management Institute (IWMI). https://www.dadoslivres.com/telecharger/controlling-floods-and-droughts-through-underground-storage-from-concept-t o-pilot-implementation-in-the-ganges-river-basin/.

5. Verry, E. S., Hornbeck, J. W., \& Dolloff, C. A. (Eds.). (1999). Riparian management in forests of the continental eastern United States. CRC Press. https://www.fs.usda.gov/treesearch/pubs/9428.

6. Sharma, N., Zakaullah, M., Tiwari, H., \& Kumar, D. (2015). Runoff and sediment yield modeling using ANN and support vector machines: a case study from Nepal watershed. Modeling Earth Systems and Environment, 1(3), 1-8. https://cese.snu.edu.in/people/faculty/nayan-sharma/. https://ink.springer.com/article/10.1007/s40808-015-0027-0 
7. Sharma, T. (2015). WATERSHED MANAGEMENT AND POLICIES IN INDIA. International Journal of Research-GRANTHAALAYAH, 3(9SE), 1-4.

8. Willems, P., Olsson, J., Arnbjerg-Nielsen, K., Beecham, S., Pathirana, A., Bülow Gregersen, I., ... \& Eng, S. J. A. P. (2013). 8.4. 2 African Development Bank's Experience Following Nexus Approach-Case Studies in Integrated Watershed Management to achieve Food Security and Sustainable Natural Resources Management from the Republic of Cape Verde, Burundi, and the Gambia. Advancing Nexus Approach to the Sustainable Management of Water, Soil and Waste, 142. https://assela.pathirana.net/index.php?title=The_book_on_Climate_Change,_Extreme_Rainfall_and_Urban_Drainage.

9. Medema, W., McIntosh, B. S., \& Jeffrey, P. J. (2008). From premise to practice: a critical assessment of integrated water resources management and adaptive management approaches in the water sector. Ecology and Society, 13(2). https://www.researchgate.net/publication/286061477_From_Premise_to_Practice_a_Critical_Assessment_of_Integrated_ Water_Resources_Management_and_Adaptive_Management_Approaches_in_the_Water_Sector.

10. Ravindranath, N. H., \& Sathaye, J. A. (2002). Climate change and developing countries. In Climate Change and Developing Countries (pp. 247-265). Springer, Dordrecht. https://www.coursehero.com/tutors-problems/Business-Other/34242542-Hi-can-you-give-me-9-scholarly-articles-to-readso-I-can-answer//.

11. Jamtsho, K., \& Gyamtsho, T. (2003). Effective watershed and water management at the local level: challenges and opportunities.

12. Bureau, R. (2005). Watershed management research: A review of IDRC projects in Asia and Latin America. Rural poverty and environment working paper series; no. 18. https://idl-bnc-idrc.dspacedirect.org/handle/10625/25832.

13. World Bank. (2007). World development report 2008: Agriculture for development. The World Bank. www.elibrary.worldbank.org..

14. Rockström, J., \& Falkenmark, M. (2015). Agriculture: Increase water harvesting in Africa. Nature News, 519(7543), 283.

15. Akudugu, M. A., Dittoh, S., \& Mahama, E. S. (2012). The implications of climate change on food security and rural livelihoods: Experiences from Northern Ghana. Journal of Environment and Earth Science, 2(3), 21-29. https://www.frontiersin.org/articles/10.3389/fsufs.2021.706721/full/.

16. Namara, R. E., Horowitz, L., Nyamadi, B., \& Barry, B. (2011). Irrigation development in Ghana: Past experiences, emerging opportunities, and future directions. https://reliefweb.int/sites/reliefweb.int/files/resources/Full_Report_228.pdf/.

17. Seddon, D., Kashaigili, J. J., Taylor, R. G., Cuthbert, M. O., Mwihumbo, C., \& MacDonald, A. M. (2021). Focused groundwater recharge in tropical dryland: Empirical evidence from central, semi-arid Tanzania. Journal of Hydrology: Regional Studies, 37, 100919.

18. Rockström, J., Falkenmark, M., Karlberg, L., Hoff, H., Rost, S., \& Gerten, D. (2009). Future water availability for global food production: The potential of green water for increasing resilience to global change. Water resources research, 45(7).

19. Aduah, M. S., Jewitt, G. P., \& Toucher, M. L. (2018). Assessing impacts of land-use changes on the hydrology of a lowland rainforest catchment in Ghana, West Africa. Water, 10(1), 9.

20. Connor, R. (2015). The United Nations world water development report 2015: Water for a sustainable world (Vol. 1). UNESCO https\%3a\%2f\%2fwww.jdoqocy.com\%2fclick-100357191-13091548\%3furl\%3dhttps\%253a\%252f\%252flink springer.com\%25 2farticle\%252f10.1007\%252fs10668-019-00506-1\%26afsrc\%3d1\%26SID\%3d.

21. Black, M. (2016). The atlas of water: mapping the World's most critical resource. Univ of California Press. https://www.amazon.com/Atlas-Water-Mapping-Critical-Resource/dp/0520259343.

22. Ntiba, M. J., Kudoja, W. M., \& Mukasa, C. T. (2001). Management issues in the Lake Victoria watershed. Lakes \& Reservoirs: Research \& Management, 6(3), 211-216. https://eijst.org.uk/articles/10.2.2.13-28.pdf.

23. Le Coz, M., Delclaux, F., Genthon, P., \& Favreau, G. (2009). Assessment of Digital Elevation Model (DEM) aggregation methods for hydrological modeling: Lake Chad basin, Africa. Computers \& Geosciences, 35(8), 1661-1670.

24. Lemoalle, J. (2004). Lake Chad: a changing environment. In Dying and Dead Seas Climatic Versus Anthropic Causes (pp. 321-339). Springer, Dordrecht.

25. UNEP, W. (2008). Freshwater Under Threat: Vulnerability Assessment of Freshwater Resources to Environmental Change-Africa. UNEP and Water Research Commission (WRC-South Africa). https://www.unep.org/resources/report/freshwater-under-threat-vulnerability-assessment-freshwater-resources.

26. United Nations Environment Programme. Division of Early Warning, Assessment, African Ministers' Council on Water, African Union. Commission, United States. Department of State \& European Union. (2010). Africa water atlas (Vol. 1). UNEP/Earth print. https://na.unep.net/atlas/africawater/downloads/chapters/africa_water_atlas_37-122.pdf.

27. FAO (2005). Food and Agriculture Organization ...http://www.fao.org > conference. The provisional agenda (document C97/1) includes technical, program, administrative, and constitutional items.

28. Robins, L. (2007). Nation-wide decentralized governance arrangements and capacities for integrated watershed management: Issues and insights from Canada. Environments: a journal of interdisciplinary studies, $35(2)$. https://www.researchgate.net/publication/260909337_Nation-wide_decentralized_governance_arrangements_and_capaci ties_for_integrated_watershed_management_Issues_and_insights_from_Canada/. 
29. Beaumont, P. (2000). The 1997 UN Convention on the Law of Non-navigational Uses of International Watercourses: its strengths and weaknesses from a water management perspective and the need for new workable guidelines. International Journal of Water Resources Development, 16(4), 475-495. https://doi.org/10.1080/713672536. 